Journal of Nepal Agricultural Research Council

Vol. 7: 92-96, April 2021

ISSN: 2392-4535 (Print), 2392-4543 (Online)

DOI: https://doi.org/10.3126/jnarc.v7i1.36927

\title{
Intermixing of Commercial Pure Breed Chickens with Indigenous (Sakini) Breed of Nepal
}

\author{
Neena Amatya Gorkhali ${ }^{1}$, Chhiring Sherpa $^{1}$, Mana Raj Kolachhapati ${ }^{2}$, Bhoj Raj Pokharel ${ }^{1}$, Nirajan \\ Bhattarai $^{3}$ and Saroj Sapkota ${ }^{1 @}$
}

\footnotetext{
${ }^{1}$ National Animal Breeding and Genetics Research Centre, Nepal Agricultural Research Council, Khumaltar, Lalitpur, Nepal @: neenagorkhali@hotmail.com, SS: sarose.sapkota@gmail.com, ORCID: https://orcid.org/0000-0002-2930-2219

${ }^{2}$ Institure of Agriculture and Animal Science (IAAS), Rampur Chitwan, Nepal

${ }^{3}$ Agriculture and Forestry University, Rampur, Chitwan, Nepal NB: nbhattarai@afu.edu.np, ORCID: https://orcid.org/0000-0003-0325-6506
}
Received 19 July 2020, Revised 09 February 2021, Accepted 05 April 2021, Published 30 April 2021
Scientific Editors: Shreeram Neopane and Gokarna Gautam
Copyright @ 2020 NARC. Permits unrestricted use, distribution and reproduction in any medium provided the original work is properly cited.
The authors declare that there is no conflict of interest.

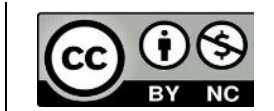

OPEN ACCESS

Licensed under the Creative Commons AttributionNonCommercial 4.0 International (CC BY-NC 4.0)

\section{ABSTRACT}

The intermixing of pure breeds of commercial chickens with Nepalese indigenous flock of chickens has not been explored yet genetically. The study aims to investigate the status of interbreeding of Nepalese indigenous chickens with exotic breeds. Thirty three samples of indigenous chicken, Sakini, from three different ecological regions, Terai, mid-hill and high hill, were taken for the study. The 522 bp hyper-variable region of D loop mtDNA of each sampled population was PCR amplified and sequenced. The Neighbor joining tree revealed that most of Nepalese Sakini and commercial chickens such as New Hampshire, Rhode Island Red, White Leghorn, White Plymouth Rock and Barred Plymouth Rock lied in same clade. Our study provides first direct evidence that the Sakini was already bred with commercial breeds for the sake of enhancing production performance and also alarms the government to introduce proper strategies and policies to avoid such genetic erosion.

Keywords: Sakini, mtDNA, intermixing, commercial breeds, genetic erosion.

\section{सारांश}

नेपाली स्थानिय जातका कुखुरा संगै व्यवसायिक कुखुरा बिच अन्तरजातिय प्रजननको बिषयमा आनुवांशिक हिसाबले अहिले सम्म कुनै खोज तथा अनुशन्धान भएको थिएन। यस अध्ययनको मुख्य उद्देश्य विदेशी जात र नेपाली रैथाने जातका कुखुराहरूको बिचको परस्पर प्रजनन प्रकृयाको बारेमा अनुसन्धान गर्नु रहेको छ। यस अध्ययनका लागि तेत्तिस रैथाने जातका साकिनी कुखुराहरूको रगतका नमुनाहरु विभिन्न तिन अलग अलग पर्यावरणीय क्षेत्र तराई, मध्य पहाडी र उच्चु पहाडबाट ल्याईएका थिए। प्रत्येक नमुनाको D loop mtDNA को ५२२ bp मा hyper-variable region मा PCR amplified र sequenced गरियो । Neighbour joining tree बाट धेरै जसो रैथाने साकिनी र व्यवसायिक कुखुरा जस्तै न्यू ह्याम्पशायर, रोड आइस्लैंड रेड, व्हाइट लेघहर्न, व्हाइट पोलिमाउथ रक र ब्यारेड पोलिमाउथ रक एकै समुह वा वर्गका रहेछन भत्ने कुरा पत्ता लाग्यो। यस अध्ययनले व्यवसायिक कुखुराका जातहरूसँगै साकिनी कुखुराको उत्पादन तथा उत्पादकत्व बृद्विमा सुधार गर्न र आनुवंशिक क्षति हुन सक्रे खतरा बाट बच्न सहि रणनिति र निति लागु गर्न सरकारलाई सहयोग मिल्नेछ। 


\section{INTRODUCTION}

The indigenous breeds, which serve as a major gene pool, are mainly raised in most of the developing countries (Bett et al., 2011). In Nepal, the poultry farming of both commercial and native stocks are in increasing trend. Dhakal (2005) revealed that the poultry sector solely encompasses $4 \%$ of the agricultural GDP in Nepal. Neopane and Gorkhali (2008) reported that 50\% of total poultry population consisted of native breeds in Nepal.Some of the documented indigenous chicken breeds of Nepal are Sakini (Normal feather), Ghatikhuile (naked neck) and Pwakh ulte (frizzled feather) (Neopane and Gorkhali, 2008). Among three indigenous chicken breeds, Sakini shares more than 50 percentage in total national poultry population (Country Report, 2014).

Sharma (2012) claimed that the poultry farming of commercial chickens have proliferated mainly in urban areas where as indigenous chickens are mostly limited in rural areas of the country because of poor access of roads and transportations. Even though these native chickens are primarily used in Family Poultry Production System (FPPS) in Nepal, the productive performances of these chickens are quite low (Sapkota et al., 2020). The productive performance of native chickens is relatively lower than other commercial breeds but they are embodied with the major genes which aid them to adapt harsh environmental conditions and resist against many diseases and parasites (Bhatti et al., 1990).

Due to poor productivity in indigenous chickens with reference to the growth, egg size and the egg production, the farmers have been introducing the pure exotic breeds in their farming systems for crossbreeding with indigenous breeds (ABD 2018; Tadella et al., 2020). The introgression of the exotic breeds on the native stocks results in the genetic erosion. Subsequently, the loss of positive attributes in indigenous breeds may occur (Gorkhali et al., 2020; Sharma et al., 2001).

Among the indigenous chicken breeds of Nepal, Sakini is the principal breed, but it has not been adequately characterized molecularly (Gorkhali et al., 2013). Sapkota et al. (2020) reported that the red jungle fowl from India was the progenitor of Sakini but the introgression of commercial chicken into this principal breed has not been studied in detail. Thus, this study aims to assess the status of interbreeding of principal breed, Sakini, with other commercial breeds.

\section{MATERIALS AND METHODS}

\section{Sampling}

Thirty three blood samples of Sakini chickens were taken from three different agro-ecological regions of Nepal (Terai, mid-hill and high hill). DNA extraction was done by following the protocol provided by Promega DNA extraction kit (Promega Korea, Republic of Korea). The quality of DNA was further assessed by using a Nanodrop spectrophotometer (Thermo Scientific ${ }^{\mathrm{TM}}$ NanoDrop 2000, China). The DNA samples were safely preserved at -20 degree Celsius until the test. Forty-two (42) reference sequences including commercial chickens, indigenous chickens and Red jungle fowl of different countries were used for analysis.

\section{PCR amplification and sequencing}

In order to amplify 522 bp long hyper-variable region of D loop mtDNA, the set of primer named L16750 and H547 (Niu et al., 2002) were used (Table 1). The final total volume of PCR reaction was made $25 \mu 1$ by adding $13 \mu \mathrm{l}$ of PCR $2 X$ Master Mix, $4 \mu 1$ of molecular grade nuclease-free water, $5 \mu 1$ of template DNA, and $1.5 \mu 1$ of each forward and reverse primers The optimum PCR condition was as follows: denaturation at $95^{\circ} \mathrm{C}$ for 1 minute, annealing at $63^{\circ} \mathrm{C}$ for 1 minute and extension at $72^{\circ} \mathrm{C}$ for 2 minutes. The amplification of 522 bp hyper-variable regions was checked by running on $1.5 \%$ agarose gel followed by visualizing under UV light by comparing with a DNA molecular weight marker (100 bp ladder). $10 \mu \mathrm{l}$ of the PCR product of each sample which showed fine amplification on agarose gel was sent to the Department of Animal Genetic Resources, National Livestock Research Institute, Rural Development Administration, South Korea for sequencing. The sequenced data were then used for comparing with mtDNA sequences of commercial chicken breeds and indigenous breeds from different countries retrieved from National Center for Biotechnology Information (NCBI). 


\section{Data analysis}

The obtained 33 mtDNA sequences of Sakini were edited by using CHROMAS software and aligned against 42 reference sequences of commercial chickens, RJF and domestic chicken of different countries by using ClustalW program of MEGA 5 software (Thompson et al., 1994). By following Kimura-2-parameter model of MEGA 5 software, Neighbour joining (NJ) phylogenetic tree was constructed (Tamura et al., 2011).

Table 1: The oligonucleotide sequences of L16750 and H547.

\begin{tabular}{lll}
\hline S.N & Primer & Oligonucleotide \\
\hline 1 & L16750 & 5'-AGG ACT ACG GCT TGA AAA GC-3' \\
\hline 2 & H547 & 5'-ATG TGC CTG ACC GAG GAA CCA G-3' \\
\hline
\end{tabular}

\section{RESULTS}

The Neighbour joining (NJ) tree revealed that the Nepalese Sakini chickens shared the same cluster with various commercial chicken breeds such as New Hampshire, White Plymouth Rock, Barred Plymouth Rock, Rhode Island Red and White Leghorn. Also major of these Sakini population share the same mtDNA D loop of domestic breeds from China and India.

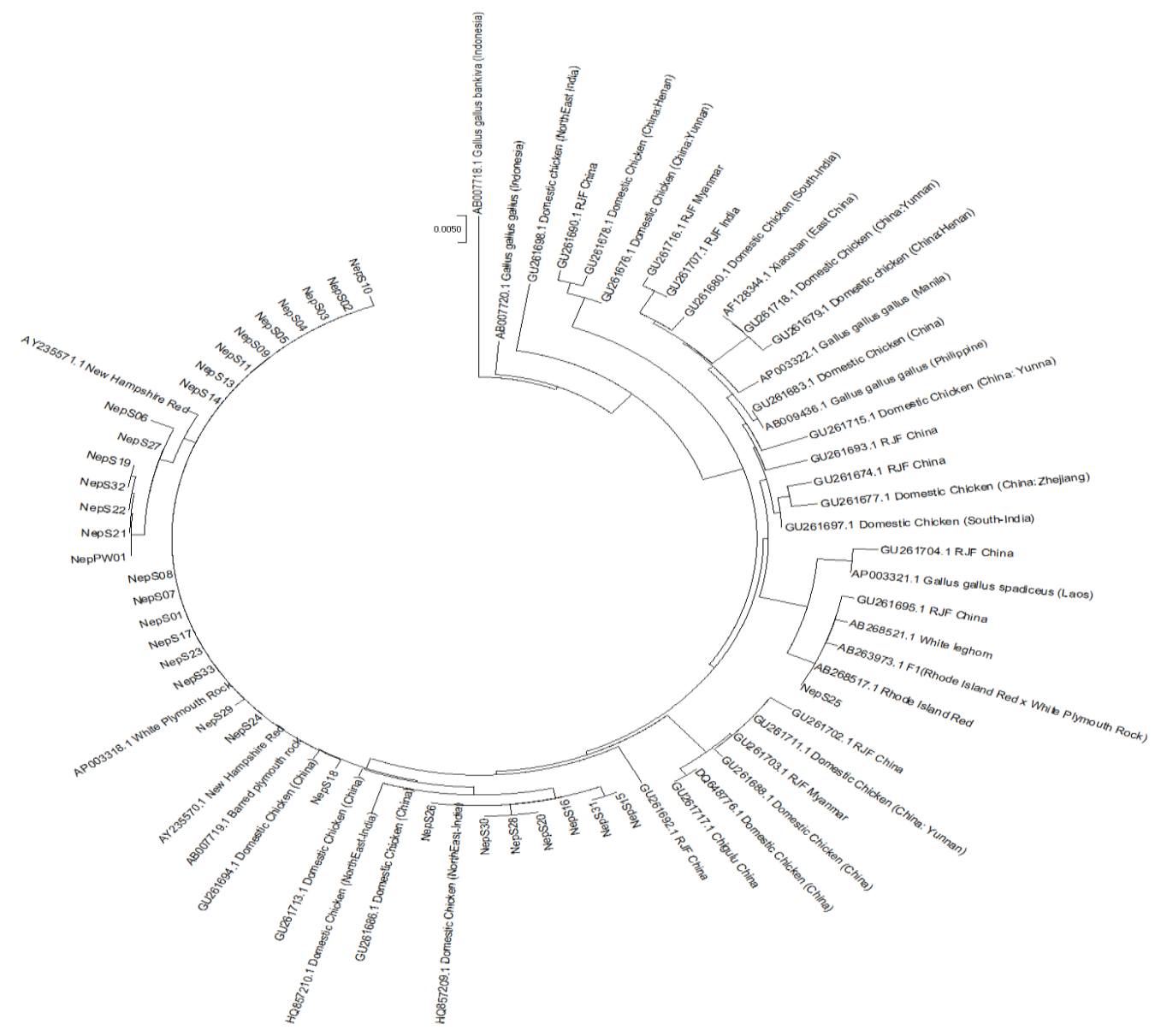

Figure 1: Un-rooted Neighbour joining tree from mtDNA D-loop sequences of Sakini chickens against commercial chickens, Red Jungle Fowls (RJF) and domestic chickens of different countries.

\section{DISCUSSION}

The commercial pure breeds such as New Hampshire was imported from India to Nepal in 1964 by the help of US funded project (FAO, 2014). Many farmers have prioritized commercial breeds as a poultry farming since Nepalese indigenous chicken breeds have lower production performance in terms of growth, egg production and egg size (ABD, 2018). Assessing the financial benefits of commercial 
poultry farming, Government of Nepal initiated various approaches and programmes to distribute it to Nepalese farmers aiming poverty reduction (Kayastha, 2010). Paucity of information is found in terms of Nepalese poultry conditions; it makes arduous to estimate the time period from when the actual crossbreeding between commercial and indigenous chicken occurred (FAO, 2014). It is reported that crossbreeding of indigenous chickens with the pure breeds of commercial chickens is popular to enhance genetic potentiality as a result an increase in production performances can be attained (Tadelle et al., 2020). Nepalese farmers may have undergone same procedure for improving the production performance of Nepalese native chickens (ABD, 2018). Yet, no promising evidence has been provided which reveals that there has been intermixing of commercial breeds of chickens with indigenous breed.

Our result provides the first evidence that our Nepalese breed, Sakini, was already bred with exotic breeds such as New Hampshire, white Plymouth Rock, Barred Plymouth Rock, Rhode Island Red and White Leghorn. Our study claiming Sakini to be close with domestic chicken breeds of India support the findings made by Bhurtel (2011) and Sapkota et al (2020). Such intermixing results in genetic erosion; as a result the native breeds may loss genes of positive attributes which are helping them to combat against extreme climatic conditions and diseases (Hosny 2005). If such intermixing continues for long run, then the Nepalese chicken will lose its genetic diversity; as a result they may no longer be able to resist against several diseases and cannot be habitant of extreme climates (Sharma et al., 2001). Our study draws attention to the government of Nepal for formulating judicious crossbreeding strategies so that the positive attributes of the indigenous chickens will not get lost. As a result genetic diversity among Sakini population can pass from generation to generation without loss of favourable genes.

\section{CONCLUSION}

This study reports the first evidence that the Nepalese Sakini breeds was already bred with different commercial pure breeds of chickens for improving genetic potentiality to enhance the productivity of the native chickens. Defined government policies with regard to crossbreeding commercial chicken with indigenous chicken populations must be formulated to prevent genetic erosion.

\section{ACKNOWLEDGEMENT}

The study was supported by AFACI-Korea: Improving Animal Genetic Resources Value and Productive Performance in Asia. The authors express sincere gratitude to scientists from International Livestock Research Institute (ILRI) and Rural Development Administration (RDA), Korea. Also authors express sincere thanks to all the staffs of Animal Breeding Division, Nepal Agricultural Research Council for their help in collecting samples.

\section{REFERENCES}

ABD. 2018. Annual Progress Report 2017/18. Animal Breeding Division (ABD), National Animal Science Research Institute, Nepal Agricultural Research Council, Khumaltar, Nepal

Anjum MA, AW Sahota, M Akram, K Javed and S Mehmood. 2012. Effect of Selection on Productive Performance of Desi chicken for four generations. Journal of Animal and Plant Sciences, 22(1): 1-5

Bhatti BM, MS Qureshi, AW Sahota and M Ashraf. 1990. Evolving of a chicken with potential of higher meat and egg yield for rural areas of Pakistan. Proceedings of third International Congress, Pakistan Veterinary Medicine Association, 3: 340-345.

Bhurtel R. 1998. Poultry Genetic Resources Proceedings of the First National Workshop on Animal Genetic Resources Conservation and Genetic Improvement of Domestic Animals in Nepal (Edited by JNB Shrestha). Nepal Agricultural Research Council, Khumaltar, Lalitpur, Nepal, 1: pp. 29-32.

Country Report. 2014. Country Report on Animal Genetic Resources of Nepal. Ministry of Agriculture Development. Department of Livestock Services, Hariharbhawan, Lalitpur.

FAO. 2014. Poultry Sector Nepal. FAO Animal Production and Health Livestock Country Reviews. No. 8. Rome.

Gorkhali, N. A., Mishra, A., Sapkota, S., Khatri-Chhetri, B. B., \&Shrestha, B. S. 2013.Quality assessment of dried meats of different lines of Sakini breed of different agro-ecological zones from central development region.In: Proceedings of 9th National Workshop on Livestock and Fisheries Research in Nepal, pp. 223240.

Gorkhali, N. A.,Sherpa, C., Budhathoki, N., Gc, S., Lama, S., Pokharel, P., Pokhrel, B. R., \& Sapkota, S. 2020. PCR Based Genotyping of Lulu Cattle of Nepal for A1, A2 Type Beta-caseins. Journal of Nepal Agricultural Research Council, 6, 56-61. DOI: https://doi.org/10.3126/jnarc.v6i0.28115 
Hosny, D. F. A. 2006. The Structure and Importance of the Commercial and Village Based Poultry Systems in Egypt. Poultry Sector Country Review (Ed. By FAO), pp. 1-39.

Kayastha, K. P. 2010. Poultry Farming Booklet (Kukhura palan pustika), Published by Central Pig and Poultry Promotion Office, Department of Livestock Services, Hariharbhavan, Lalitpur, Kathmandu, Nepal.

Neopane SP and NA Gorkhali. 2008. Indigenous chickens of Nepal. Animal Breeding Division, Nepal Agricultural Research Council, Khumaltar, Nepal.

Niu, D., Fu, Y., Luo, J., Ruan, H., Yu, X.-P., Chen, G., \& Zhang, Y.P. 2002.The origin and genetic diversity of Chinese native chicken breeds.Biochemical Genetics, 40(5/6), pp. 163-174.

Tadelle D, Y Alemu and KJ Peters. 2000. Indigenous chickens in Ethiopia: Genetic potential and attempts at improvement. World Poultry Science Journal, 56: 45-54.

Sapkota, S., Kolakshyapati, M. R., Devkota, N. R., Bhattarai, N., \& Gorkhali, N. A. 2020. Selective Breeding to Improve Productive and Reproductive Performances and Survivability of Indigenous Sakini Chicken. Journal of Nepal Agricultural Research Council, 6, 62-69. DOI: https://doi.org/10.3126/jnarc.v6i0.28116

Sharma D, Appa RKBC, Singh RV, Totey SM. 2001. Genetic diversity among chicken breeds estimated through randomly amplified polymorphic DNA. AnimBiotechnol 12:111-20.

Tadelle, D., Alemu, Y., \& Peters, K. J. (2000). Indigenous chickens in Ethiopia: Genetic potential and attempts at improvement. World's Poultry Science Journal, 56(1), 45-54. DOI : https://doi.org/10.1079/WPS20000005

Tamura, K., Peterson, D., Peterson, N., Stecher, G., Nei, M., \& Kumar, S. 2011. MEGA5: Molecular Evolutionary Genetics Analysis Using Maximum Likelihood, Evolutionary Distance, and Maximum Parsimony Methods. Molecular Biology and Evolution, 28(10), 2731-2739. DOI : https://doi.org/10.1093/molbev/msr 121

Thompson, J. D., Higgins, D. G., \& Gibson, T. J. 1994. CLUSTAL W: Improving the sensitivity of progressive multiple sequence alignment through sequence weighting, position-specific gap penalties and weight matrix choice. Nucleic Acids Research, 22(22), 4673-4680. DOI: https://doi.org/10.1093/nar/22.22.4673

||------||-------|| 